\title{
Evaluation of engineered barrier system for hazardous waste disposal - A case study
}

\author{
Gandhi G. N. ${ }^{\text {i) }}$ Sivakumar Babu G. L. ${ }^{\text {ii) }}$ and Santhosh L. G. ${ }^{\text {iii) }}$ \\ i) Former Director, LJIET, Ahmedabad 382210, India. \\ ii) Professor, Department of Civil Engineering, Indian Institute of Science, Bangalore 560012, India. \\ iii) Ph.D Student, CST, Indian Institute of Science, Bangalore 560012, India.
}

\begin{abstract}
The management of Hazardous Waste (HW) has become a very important and serious matter because of installation of large number of industries across India as a part of globalization and industrialization. If improperly managed, the HW would lead to environment holocaust. Hazardous waste (HW) landfills are provided with either single liner or double liner system to avoid subsurface soil and groundwater contamination due to leachate. These liners are multi layered multi barrier system which typically consists of leachate collection and removal system, compacted clay barrier soil and geosynthetic materials. In the present study, three types of HW landfill configurations are analyzed for hydrological performance using HELP model, to estimate the quantity of leachate generated and estimate the leakage through considered liner systems. Based on the performance, it could be recommended to provide a single liner system with geosynthetic Clay Liner (GCL) for the considered HW landfill. The thickness of the compacted clay liner (CCL) is reduced by $60 \mathrm{~cm}$ and a GCL of thickness $7 \mathrm{~mm}$ is instead provided in the recommended liner system which performs much better than single and double liner system while reducing the quantity of clay soil. The paper also presents various aspects employed in the landfill for the disposal of hazardous waste.
\end{abstract}

Keywords: hazardous waste, single and double liner system, GCL, HELP model.

\section{INTRODUCTION}

The management and disposal of solid/hazardous waste has become a challenging issue to the engineers in the present era. Hazardous waste (HW) disposal methods include landfill, mine shaft and deep well injection techniques. Landfill has been most commonly practiced method of waste disposal. Disposal of hazardous waste however, requires isolation of waste from the environment as it may be fatal to living beings and contaminate the environment. The Resource Conservation and Recovery Act (RCRA) of the United States defines hazardous waste as "a solid waste, a combination of solid wastes, which because of its quantity, concentration, or physical or chemical characteristics may (1) cause or significantly contribute to an increase in mortality or an increase in serious irreversible or incapacitating reversible illness or (ii) pose a substantial present or potential hazard to human health or the environment when improperly treated, stored, transported or disposed off or otherwise managed". The important characteristics used by EPA for identifying the wastes as HW are (i) Ignitability (ii) Corrosivity (iii) Reactivity (iv) Toxicity.

The three Rs of Waste Management in order of importance are: Reduce, Reuse and Recycle followed by Energy recovery with heat and power, Treatment and finally Disposal in Landfill. The recommended design criteria for a safe Landfill are:

- Location: HW landfills shall not be located within a distance of 200 meter of any lake or pond, 100 meter of a navigable river or stream, 500 meter of right of way of any state or national highway, 500 meter of a notified habituated area or public park or within a 200 year flood plain. No landfill shall also be located in areas where ground water table is expected to be within 2 meter below base of the landfill.

- Design Life: Design life typically shall range from 10 years to 25 years depending upon availability of land area. The "Closure and Post closure" period for which landfill to be monitored and maintained shall be 30 years after "active period" is completed.

- Classification of Landfill: Landfills may be classified as small size if landfill is less than 5 hectare, medium size for area 5 to 20 hectares and large size if area is over 20 hectares.

- Phased Operation: Landfill shall be operated in phases because it allows progressive use of landfill area such that at any given time, a part of site may have final cover, a apart being actively filled, a part 
being prepared to receive waste and a part undisturbed.

- Liner System: In regions where rainfall is high and/or subsoil is highly permeable (e.g. gravel, sand, silty sand) and/or where the water table is within $2 \mathrm{~m}$ to $6 \mathrm{~m}$ beneath the base of landfill, the liner system shall be double composite liner system. If the water table is more than 6 meter beneath the base of the landfill, the liner system shall be single composite liner system (1.5 meter clay liner + HDPE liner).

A typical HW landfill consists of waste surrounded by cover system on the top and liner system at the bottom. The cover system, single liner and double liner systems specified by Central Pollution Control Board (CPCB) of India, (2001) for HW landfills are used in this study. For several decades, covers have been used to protect human health and the environment against exposure to contaminants in waste disposal sites (Daniel and Koerner 1993; Rowe et al. 2004; Staub et al. 2011; Benson et al. 2012).

Traditionally compacted clay had been extensively used in the cover and composite barrier liner systems. However, the underperformance and failures of clay barrier systems led to the emergence and usage of synthetic flexible membranes in composite barrier system. Rowe et al. (2004) reported that reliability of clay liners has been a contentious issue and number of failures has led to use the geomembrane and geosynthetic liner along with clay liners. There have been numerous studies that have evaluated a wide variety of polymers as flexible geomembrane liners for landfills. The most widely used membrane liners for landfill applications include polyolefins, chlorinated and chlorosulfonated polyolefins, and compounds based upon polyvinyl chloride. Many of the more recent landfill installations have made use of black polyethylene with high environmental-stress crack resistance. GCLs are one among the synthetic materials used in landfill lining. GCLs have become an established replacement for compacted clay in landfill basal liners and cover systems since their introduction in the 1980s (Mazzieri and Pasqualini 2000). GCLs are comprised of a thin layer of sodium or calcium Bentonite bonded to a layer or layers of geosynthetic materials. These geosynthetics are either geotextiles or a geomembrane. Geotextiles-based GCLs are bonded with an adhesive, needle punching or stitch-bonding, with the Bentonite contained by the geotextiles on both sides. Flexible membrane liners are typically polymers or compounds with additives to improve their physical and chemical properties. The chemical and physical properties of these synthetic liners should be weighed carefully in order to ensure both long life and costeffectiveness of the liner system. These properties of liners in landfill service are functions of molecular weight, molecular weight distribution, chemical structure, copolymer or additive enhancement, and the degree of cross-linking. Based upon present technology, this type of liner is probably the most cost-effective solution to the selection of flexible membrane liners for landfills that contain hazardous wastes. A good liner system is characterised by maximum drainage and minimum leakage. In the present study the hydraulic performance of the GCLs in combination with other liners specified by CPCB are evaluated using HELP (the Hydrologic Evaluation of Landfill Performance) model. A part of the compacted clay liner is replaced by GCL in the bottom liner and the layer is analyzed. Both single and double liner systems are also analyzed. The best configuration in terms of maximum drainage and minimum leakage is suggested and recommended for use in the bottom liner system.

\section{STUDY AREA AND SITE DESCRIPTION}

Ankleshwar is a city ten kilometres away from Bharuch district in the state of Gujarat, India. The town is known for its industrial township called GIDC (Gujarat Industrial Development Corporation). Ankleshwar has over 1000 chemical plants, producing products such as pesticides, pharmaceuticals, chemicals, and paints. Ankleshwar Industrial Estate (AIE) is the largest chemical estate in Asia, covering $16 \mathrm{~km}^{2}$ and housing nearly 1600 units in different sectors, including 400 chemical units. The plants in Ankleshwar process large quantities of basic chemicals, solvents, acids, and fuels to manufacture more than $25 \%$ of Gujarat's output of pharmaceuticals, chemicals, pesticides, dyes and intermediaries. The hazardous waste generated by these industrial plants is disposed off in a secured $\mathrm{HW}$ landfill. Bharuch Enviro Infrastructure Ltd (BEIL) has set up common Hazardous Waste Treatment, Storage \& Disposal Facility with Secured Landfill, Common Incineration System, Bio Gas Plant and other infrastructure. The secured landfill facility is in operation since 1998 and is estimated to be operational for a period of 15-20 years and therefore, simulations are carried out for a period of 20 years in the present study. The height of the landfill from bottom as reported by Jose et al 2003 is $12-15 \mathrm{~m}$. During the 5 years of operation, the Company has collected and disposed off more than 200,000 MT of solid/hazardous wastes from member industries. Two cells have already been provided top coverage. The Hazardous Waste (Management and Handling) Rules 2001 and "Criteria for Hazardous Waste Landfills" published by CPCB are being implemented. Presently five layers of asphaltic concrete have been provided as liner system in the landfill. However, the introduction of GCLs in the liner systems for future operations may reduce cost and the impact on the environment. 


\section{COVER AND LINER SYSTEM FOR HW LANDFILLS}

The specifications provided by CPCB for cover system, single and double liner system are used for analysis in this study. Additionally a single liner system in combination with GCL are analysed in order to examine the effectiveness and usage of the same.

\subsection{Cover system for HW landfills}

The main purpose of installing a cover system is to minimize the infiltration of rainfall, enhance surface drainage, and control release of toxic gasses into the environment and support vegetation growth which helps to control surface erosion of soil. The cover system must be designed based on the site location and regional meteorological data which includes precipitation, temperature and other weather parameters. The minimum specifications of the cover system as shown in Figure 1 are given below:

- A surface layer of local top solid which supports self-sustaining vegetation and which has a thickness not less than $60 \mathrm{~cm}$.

- A drainage layer of thickness $30 \mathrm{~cm}$ or more having a coefficient of permeability in excess of $10^{-2}$ $\mathrm{cm} / \mathrm{sec}\left(10^{-4} \mathrm{~m} / \mathrm{sec}\right)$.

- An HDPE geomembrane $1.5 \mathrm{~mm}$ thick or more and a compacted clay layer of thickness $60 \mathrm{~cm}$ or more having a coefficient of permeability of $10^{-7} \mathrm{~cm} / \mathrm{sec}$ $\left(10^{-9} \mathrm{~m} / \mathrm{sec}\right)$ or less. A regulatory layer (optional) of thickness $30 \mathrm{~cm}$ having coefficient of permeability greater than $10^{-2} \mathrm{~cm} / \mathrm{sec}\left(10^{-4} \mathrm{~m} / \mathrm{sec}\right)$. Such a layer shall be provided whenever there is requirement of gas collection or transition filter between waste and soil.

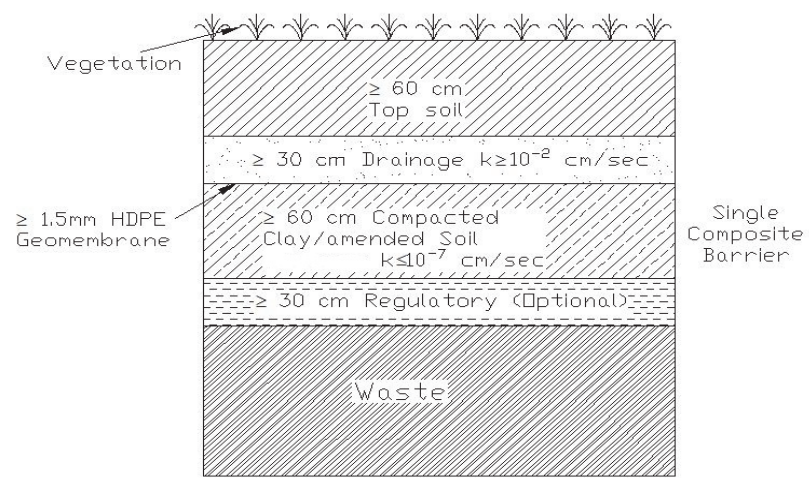

Fig. 1. Cover system for Hazardous waste landfill, CPCB, 2001

\subsection{Liner systems for HW landfills}

The guidelines given by CPCB (2001) also emphasize adoption of single liner system or double liner system depending upon the rainfall, type of subsoil and the water table beneath the base of the landfill. In a place where rainfall is high and /or sub-soil is highly permeable (e.g. gravel, sand, silty sand) and /or the water table is within $2.0 \mathrm{~m}$ to $6.0 \mathrm{~m}$, the guidelines suggest to adopt double composite liner system. The specifications of the single composite liner (Figure 2a), and double composite liner system (Figure 2b) are presented in this section.

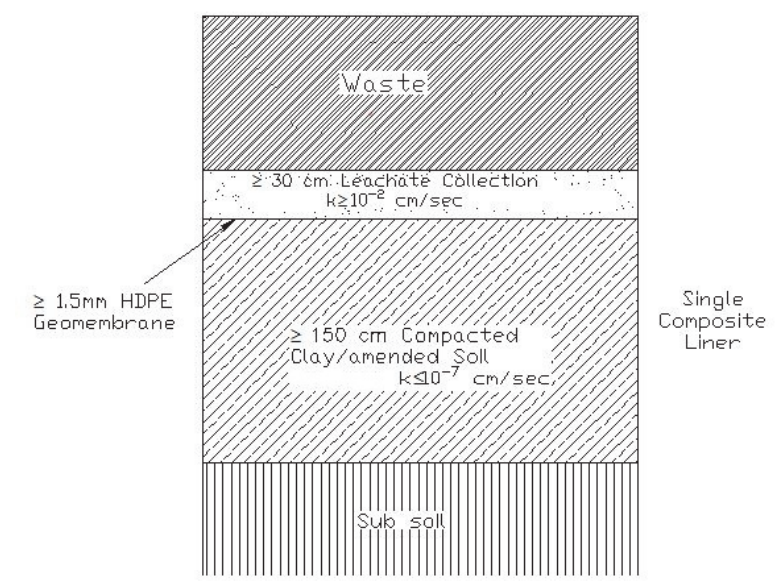

(2a)

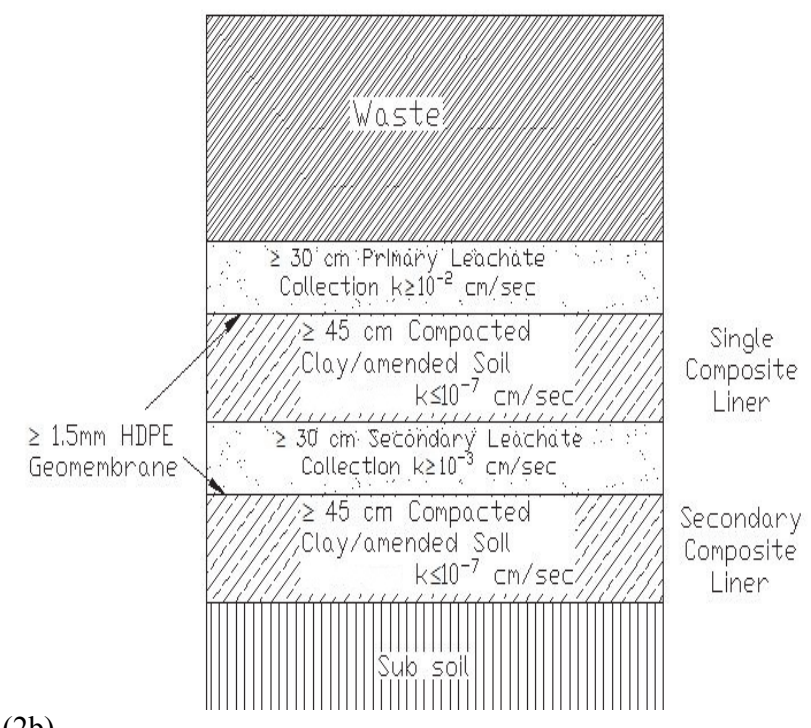

Fig 2. Liner system for HW landfills, CPCB, 2001. 2a) Single Liner system (SL) 2b) Double Liner system (DL)

Specifications of the single composite liner system:

- A leachate collection layer of thickness $30 \mathrm{~cm}$ or more and co-efficient of permeability in excess of $10^{-2} \mathrm{~cm} / \mathrm{sec}\left(10^{-4} \mathrm{~m} / \mathrm{sec}\right)$.

- A single composite liner comprising of an HDPE geomembrane of thickness $1.5 \mathrm{~mm}$ or more and a compacted clay layer of thickness $150 \mathrm{~cm}$ or more having a coefficient of permeability of $10^{-7} \mathrm{~cm} / \mathrm{sec}$ $\left(10^{-9} \mathrm{~m} / \mathrm{sec}\right)$ or less.

Specifications of double composite liner system:

- A primary leachate collection layer of thickness 30 $\mathrm{cm}$ or more and co-efficient of permeability in excess of $10^{-2} \mathrm{~cm} / \mathrm{sec}\left(10^{-4} \mathrm{~m} / \mathrm{sec}\right)$. 
- A primary composite liner comprising of an HDPE geomembrane of thickness $1.5 \mathrm{~mm}$ or more and a compacted clay layer of thickness $45 \mathrm{~cm}$ or more having a coefficient of permeability of $10^{-7} \mathrm{~cm} / \mathrm{sec}$ $\left(10^{-9} \mathrm{~m} / \mathrm{sec}\right)$ or less

- A secondary leachate collection layer (also called leak detection layer) of thickness $30 \mathrm{~cm}$ or more and co-efficient of permeability in excess of $10^{-3}$ $\mathrm{cm} / \mathrm{sec}\left(10^{-5} \mathrm{~m} / \mathrm{sec}\right)$

- A secondary composite liner comprising an i) HDPE geomembrane of thickness $1.5 \mathrm{~mm}$ or more ii) A compacted clay layer of thickness $45 \mathrm{~cm}$ or more having a co-efficient of permeability of $10^{-7}$ $\mathrm{cm} / \mathrm{sec}\left(10^{-9} \mathrm{~m} / \mathrm{sec}\right)$ or less.

\subsection{Single liner system with GCL for HW landfill}

Single liner system specified by CPCB (2001) consists of $150 \mathrm{~cm}$ thick compacted clay layer. Koerner and Daniel (1995) evaluated the hydraulic equivalency of GCL and CCL by equating the fluxes through GCL and CCL. According to the Equation-1, for a head of leachate $\mathrm{h}=30 \mathrm{~cm}, 60 \mathrm{~cm}$ thick CCL with $\mathrm{k}_{\mathrm{CCL}}=1 \times 10^{-7}$ $\mathrm{cm} / \mathrm{s}$, the equivalent GCL which is about $\mathrm{t}_{\mathrm{GCL}}=0.7 \mathrm{~cm}$ thick should have hydraulic conductivity $\left(\mathrm{k}_{\mathrm{GCL}}\right)$ of $3.4 \times 10^{-9} \mathrm{~cm} / \mathrm{sec}$.

$$
\left(k_{G C L}\right)_{R e q}=k_{C C L} \frac{t_{G C L}}{t_{C C L}} \frac{h+t_{C C L}}{h+t_{G C L}}
$$

The hydrological evaluation of this combination as presented in Figure 3 is performed using HELP model and the parameters like drainage and leakage are analysed.

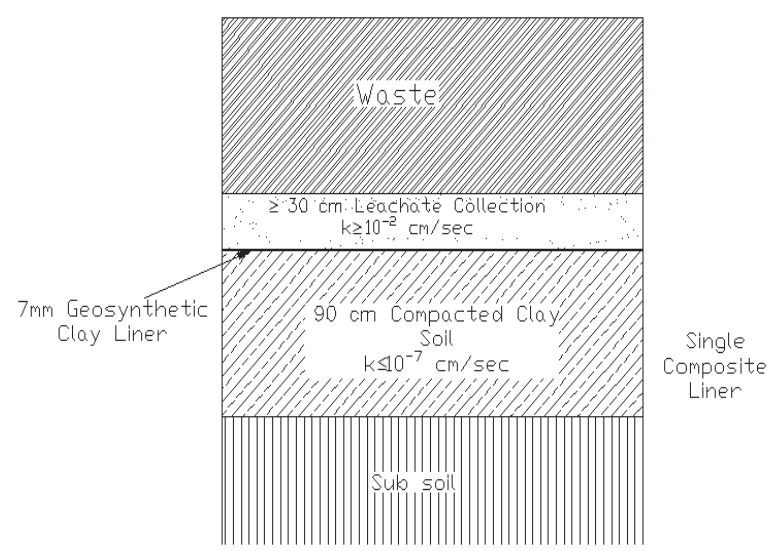

Fig 3. Single liner system with GCL (SL_GCL) considered in this study

\section{METHODS}

\subsection{HELP model and generation of weather data}

The hydrologic model water balance method is the most widely used approach to estimate infiltration or percolation rate (I) through the porous media (Benson and Khire, 1995; Hauser et al., 2005; Khire et al., 1997; William et al., 2004, 2013). This method considers hydrological parameters precipitation $(\mathrm{P})$, Surface
Runoff (RO), Evapotranspiration (ET) for the region under study to establish a relation between inflow and outflow from a system. According to this method, amount of water infiltrated (I) to the material can be obtained by subtracting surface runoff and evapotranspiration from precipitation. Change in moisture content of the soil or waste material is considered as water storage $(\delta \mathrm{S})$ as given in Equation-2. The inter-relationships between climate, vegetation and soil characteristics, and their effects on ET and infiltration (vertical drainage) are complex to understand (Peyton and Schroeder, 1988).

$$
I=P-E T-R O \pm \delta S
$$

Hydraulic Evaluation of Landfill Performance (HELP) is one of the most widely used numerical models to evaluate the cover system (Schroeder et al., 1994a, 1994b). These models are used to evaluate the relative expected performance of leachate collection system, which works on the principle of water balance method using the Equation-1. HELP is a quasi twodimensional hydrologic model of water movement across, into, through, and out of landfills that it is used to estimate the leachate generation rate of landfills under the site specific climatologic conditions. The HELP model is most appropriate for humid and semi humid areas. HELP model considers engineering properties of the materials such as porosity, field capacity, wilting point and saturated hydraulic conductivity of materials as input to study the performance. Weather data is generated using the Social Weather Stations (SWS) weather generator built-in tool in the HELP model based on the historical climate data for a simulation period of 20 years. Weather data includes precipitation, temperature and solar radiation for Surat, Gujarat, India. Since Surat and Bharuch are adjacent districts around $50-60 \mathrm{~km}$ apart, the weather data of Surat is used in this study.

In the present study three types of liner systems are analysed while the configuration of the cover system is kept unchanged. A single liner system, double liner system and a single liner system with GCL are analysed for drainage and leakage using HELP model and best configuration is suggested. Table-1 shows the properties of the different layers used in this study. 
Table 1.Properties of landfill component considered in the study.

\begin{tabular}{|c|c|c|}
\hline $\begin{array}{l}\text { Landfill } \\
\text { component }\end{array}$ & Property & Value \\
\hline \multirow{2}{*}{$\begin{array}{l}\text { Drainage layer- } \\
\text { Garvel }\end{array}$} & Total porosity & $0.417 \mathrm{vol} / \mathrm{vol}$ \\
\hline & $\begin{array}{l}\text { Field capacity } \\
\text { Wilting point } \\
\text { Sat. hydraulic } \\
\text { conductivity }\end{array}$ & $\begin{array}{l}0.045 \mathrm{vol} / \mathrm{vol} \\
0.018 \mathrm{vol} / \mathrm{vol} \\
1 \mathrm{E}-2 \mathrm{~cm} / \mathrm{s}\end{array}$ \\
\hline \multirow{3}{*}{$\begin{array}{l}1.5 \mathrm{~mm} \text { thick } \\
\text { Geomembrane } \\
\text { Liner-HDPE } \\
\text { material }\end{array}$} & $\begin{array}{l}\text { Sat. hydraulic } \\
\text { conductivity }\end{array}$ & $2.00 \mathrm{E}-11 \mathrm{~cm} / \mathrm{s}$ \\
\hline & $\begin{array}{l}\text { Pinhole density } \\
\text { Installation } \\
\text { defects }\end{array}$ & $\begin{array}{l}15 \mathrm{nos} / \mathrm{ha} \\
2 \mathrm{nos} / \mathrm{ha}\end{array}$ \\
\hline & $\begin{array}{l}\text { Placement } \\
\text { quality }\end{array}$ & Good \\
\hline \multirow{4}{*}{$\begin{array}{l}\text { Barrier soil liner- } \\
\text { Clay, moderately } \\
\text { compacted }\end{array}$} & Total porosity & $0.451 \mathrm{vol} / \mathrm{vol}$ \\
\hline & Field capacity & $0.419 \mathrm{vol} / \mathrm{vol}$ \\
\hline & Wilting point & $0.332 \mathrm{vol} / \mathrm{vol}$ \\
\hline & $\begin{array}{l}\text { Sat hydraulic } \\
\text { conductivity }\end{array}$ & $6.8 \mathrm{E}-7 \mathrm{~cm} / \mathrm{s}$ \\
\hline \multirow[t]{2}{*}{$\overline{\mathrm{GCL}}$} & Thickness & $7 \mathrm{~mm}$ \\
\hline & $\begin{array}{l}\text { Sat hydraulic } \\
\text { conductivity }\end{array}$ & $2.00 \mathrm{E}-12 \mathrm{~cm} / \mathrm{s}$ \\
\hline
\end{tabular}

\section{RESULTS AND DISCUSSIONS}

Three different types of liner systems (SL-Single liner system, DL-double liner system and SL_GCLsingle liner system with GCL) are analysed using HELP model in the present study. The simulations are carried out for 20 years period as the estimated operational period of the Ankleshwar landfill is around 15-20 years. The weather data is simulated using historical rainfall data of a weather station in Surat, Gujarat, India, which represents the post closure condition of the landfill. The generated water balance components like precipitation, runoff and evaporation for the Ankleshwar area are presented in Figure-4. The drainage and leakage are obtained based on the inputs provided. The precipitation is calculated based on previous data and this serves as the major input for analysis. The precipitation and runoff are maximum $(160 \mathrm{~cm}$ and $100 \mathrm{~cm})$ in the $16^{\text {th }}$ year but the evaporation rate does not vary significantly.

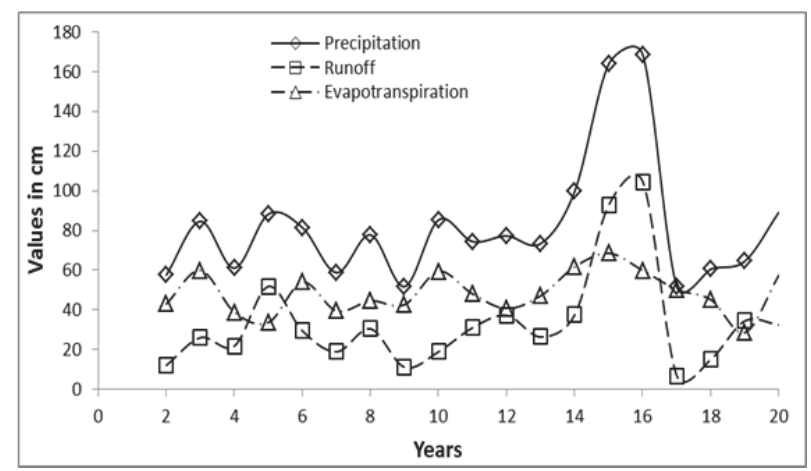

Fig.4. Simulated water balance components for Surat, India

The Figure- 5 shows the variation of leakage through liner with time. It is evident from the graph that the maximum leakage occurs through the single liner system $\left(32 \mathrm{~m}^{3}\right)$ and minimum for single liner system with GCL $\left(0.2 \mathrm{~m}^{3}\right)$ at the end of 20 years. Around $25 \mathrm{~m}^{3}$ of leakage was developed in case of double liner system. GCLs may be subjected to minor damages and punctures while handling and installation operations in the field. However the self-healing properties of bentonite in saturated condition increase the performance of the liner system. Hydration or swelling behaviour of bentonite used in GCLs largely influences containment as well as the sealing effect of GCLs (Babu et al 2001). Whereas the damages that are caused in the clay liners and geo membranes do not heal as in the case of GCL and lead to maximum leakage. Phillips and Eberle (2001) concluded that GCL has high durability, saves about $20 \%$ of cost and is easy to install. It is evident that SL_GCL has the least leakage among the three considered liner systems.

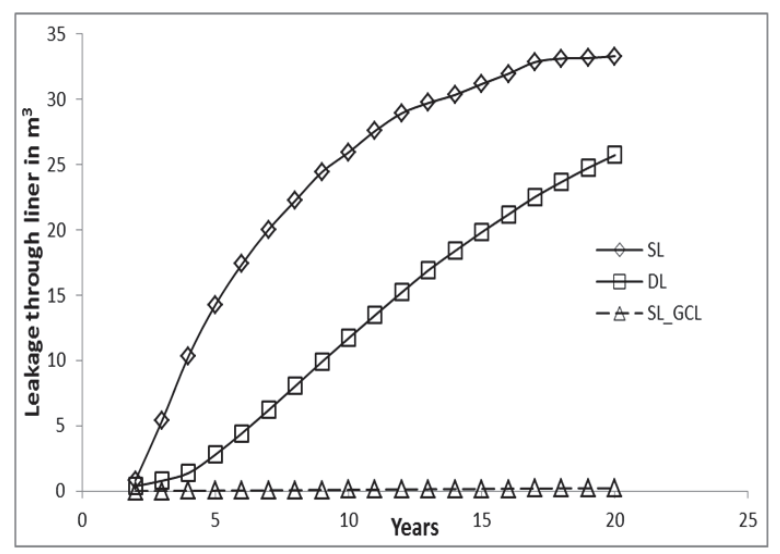

Fig. 5. Variation of leakage through liner with time for the simulated period of 20 years

The lateral drainage of the considered liner systems are shown in Figure-6. The lateral drainage is $0.42 \mathrm{~m}^{3}$ in SL GCL and $0.02 \mathrm{~m}^{3}$ and $0.03 \mathrm{~m}^{3}$ in DL and SL at the end of 20 years. There is maximum drainage occurring in SL_GCL which implies that the GCL does not allow the leachate to stagnate or pass through it. Whereas in the other two cases where the GCL is absent, the leachate may seep through the weak joints or holes created due to excess pressure on the membranes. Both leachate accumulation and leakage can lead to the failure of the landfill liner system and pollute the environment. Though several parameters like slope and overburden pressure have an effect on the liner system, the presence of GCLs improves the performance of the liner systems. 


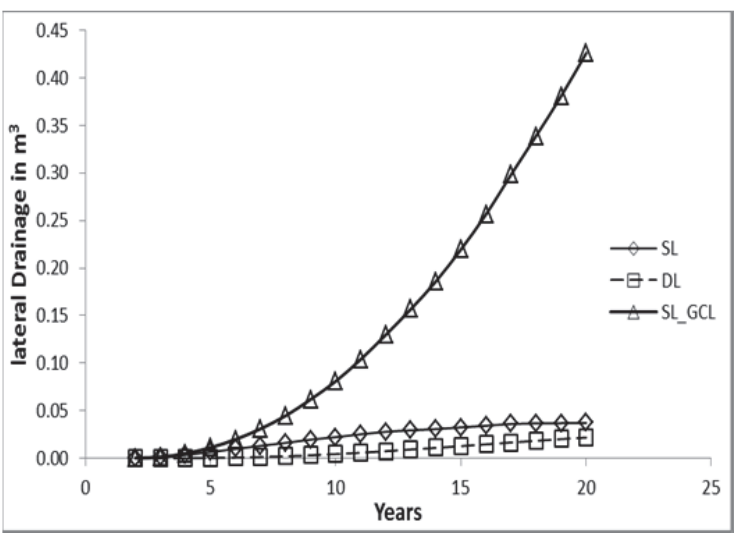

Fig. 6. Variation of lateral drainage with time for the simulated period of 20 years

\section{CONCLUSIONS}

This study focuses on the evaluation of the performance of engineered barrier system. A single liner system, double liner system and a single liner system with GCL have analysed in this study using HELP model. The standard specifications prescribed by the CPCB were considered for the single and double liner system. In the third type, GCL replaced around 60 $\mathrm{cm}$ of compacted clay in the single liner system. The simulated results show that thickness of each layer and the presence of GCL have a significant influence on leakage and lateral drainage of the considered liner systems. The following conclusions can be drawn from the present study:

- The presence of GCL reduces the leakage through the liner and maximises the lateral drainage.

- GCL also reduces the thickness of compacted clay to $1 / 3^{\text {rd }}$ and effectively reduces quantity of clay soil required and the cost as well.

- The GCL can reduce the thickness of the liner system without affecting its performance.

- GCL has greater strain tolerance, less potential for desiccation and cracking and better control of rainfall infiltration.

Use of GCLs in both cover and liner system can significantly reduce the thickness of the barrier system and cost without affecting the performance. Therefore, a single liner system with GCL can be recommended for the Ankleshwar landfill site for future operations. Though CPCB specifies single and double liner system, a single liner system with GCL seems to perform better in terms of reducing leakage through liner and increasing lateral drainage. Also the usage of GCL in the cover system may further improve the hydrological performance of the engineered barrier system. Also GCLs can be effectively used to augment or replace compacted clay or geomembranes in either the base liner or the final capping system.

\section{ANKLESHWAR HW LANDFILL}

The landfill at Ankleshwar is amongst the first well designed HW treatment, incineration and land filling facility in the country which came up in early 1990's. The Figures 7 to 13 show various aspects employed for the landfill.

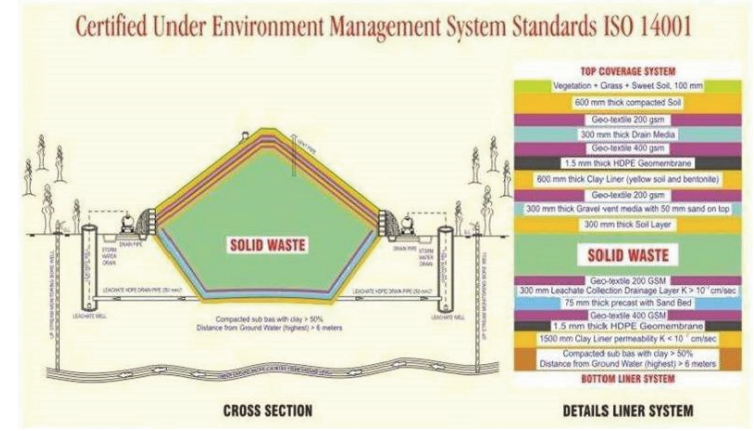

Fig. 7. Details of liner system, Ankleshwar HW landfill

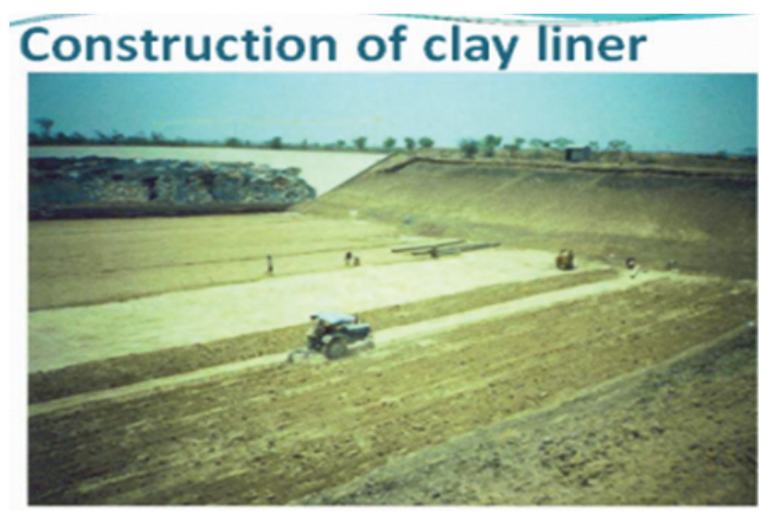

Fig. 8. Construction of clay liner, Ankleshwar HW landfill

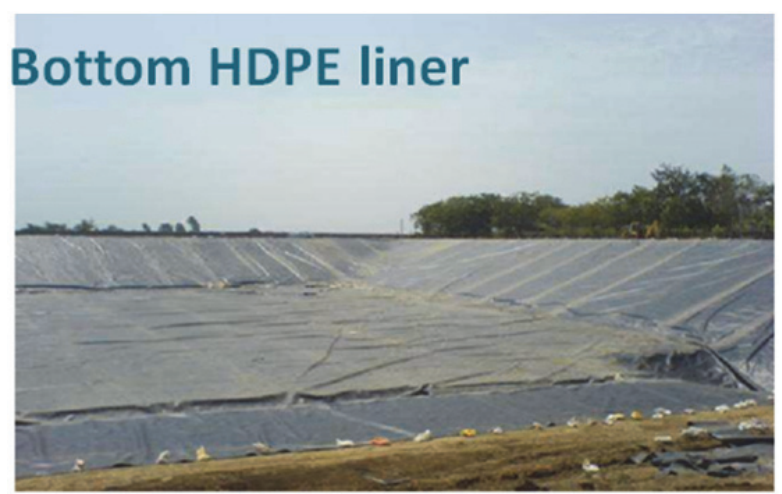

Fig. 9. Bottom HDPE liner, Ankleshwar HW landfill 


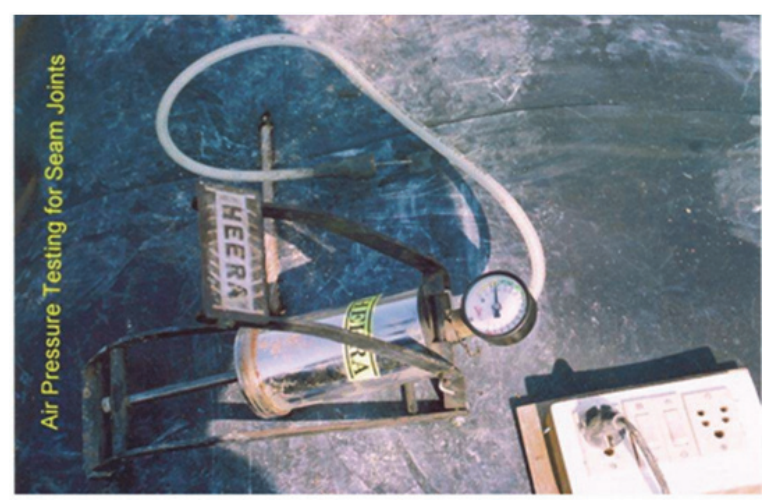

Fig. 10. Testing of HDPE joints welding

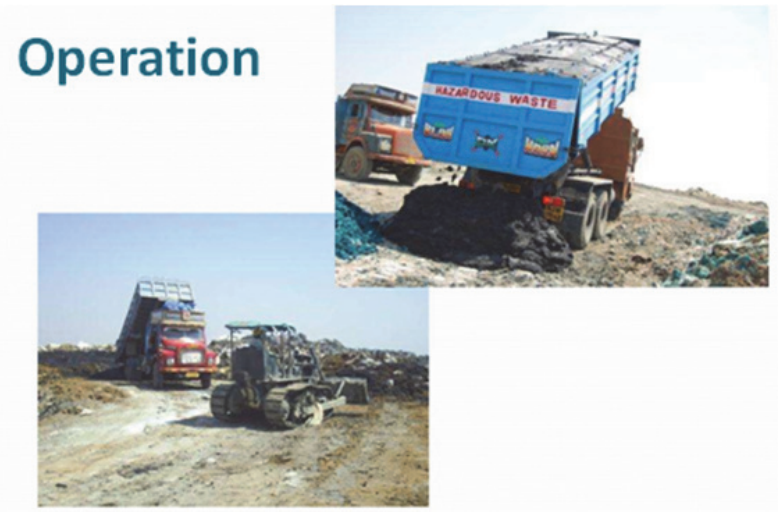

Fig. 11.Waste filling operation in Ankleshwar HW landfill

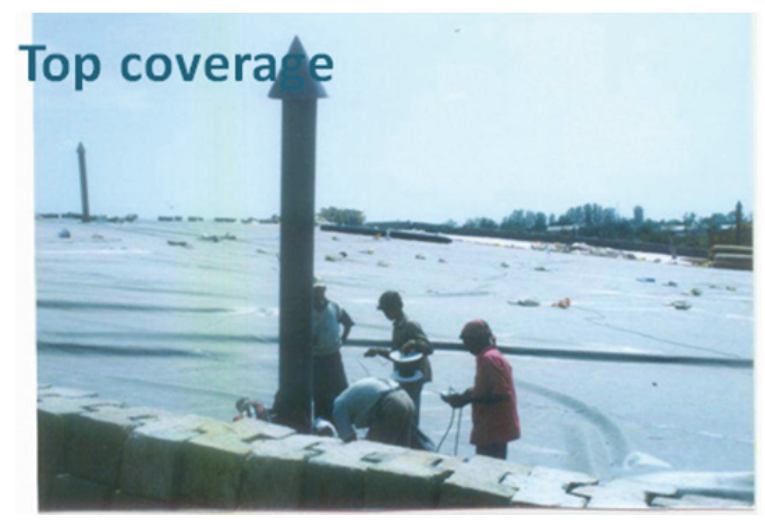

Fig. 12. Top coverage and gas vent in Ankleshwar HW landfill

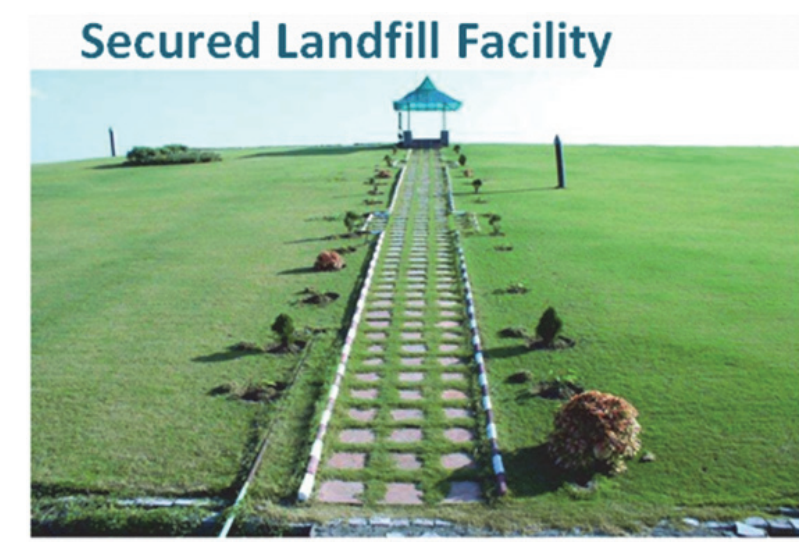

Fig. 13. Secured facility, Ankleshwar HW landfill
The design of the landfill is done one phase at a time every year. Over the past few years, as reported by Datta (2012), the following lessons can be learnt:

a) Lesson A- Site investigations for each phase are must: In 2007, a new phase was designed adjacent to an existing phase. No site investigations were carried out as it was felt that the new phase was within a distance of $100 \mathrm{~m}$ of the existing phase for which site investigation results were available. When excavation was begun, to a depth of $8 \mathrm{~m}$, water table was encountered at $7 \mathrm{~m}$ depth at one end of the excavation (Figure 14). This was surprising because the water table depth was estimated at $15 \mathrm{~m}$ on the basis of earlier site investigations. The water table was observed to be a perched water table. Its presence delayed the development of the new phase. If site investigations would have been conducted for the new phase, proper design measures would have resulted in timely development of the phase.

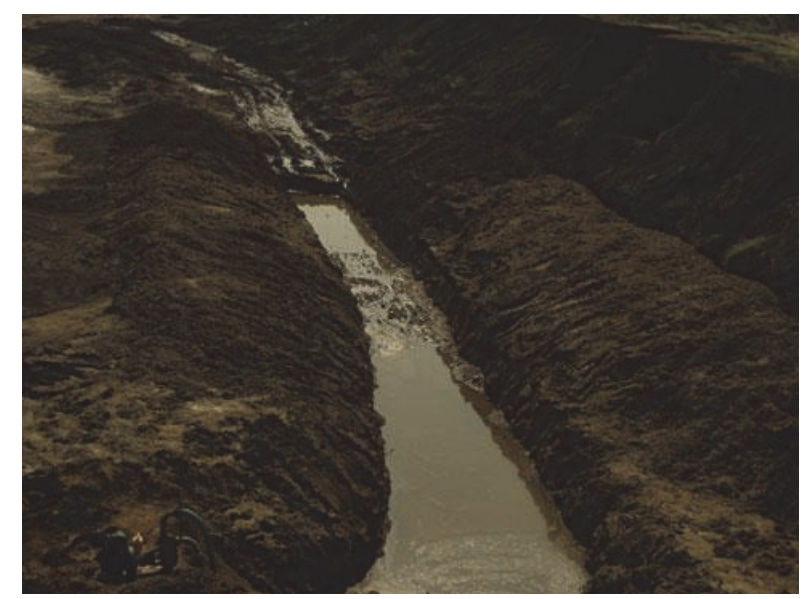

Fig. 14. Perched water table, Ankleshwar HW landfill

(b) Lesson B - side slopes can become unstable during monsoons: The side slopes of the liner at Ankleshwar landfill in the excavated portion are of the order of $2.5(\mathrm{H}): 1.0(\mathrm{~V})$ and the cover slopes are of the order of 5.0:1.0. The side slopes in the excavated portion are observed to be very stable during the dry months, but on one occasion, slippage was observed during the monsoons when water gained access to the excavated portion and cascaded down the side slope during a heavy downpour. This portion was subsequently repaired. Stability is compromised when excess water flows downwards, parallel to the outer slope. This situation should be avoided by using proper surface water drainage measures.

(c) Lesson C-Leakage Detection System (LDS) along straight lines is economical: The Ankleshwar landfill has a single composite barrier as its liner system comprising of a $1.5 \mathrm{~mm}$ thick HDPE geomembrane underlain by a $1.5 \mathrm{~m}$ thick 
compacted clay layer. It is not feasible to detect leakage in such a liner as can be done in the case of a double liner system. To overcome this shortcoming, three types of LDS were conceptualized and compared-a 'multipoint' detection system, a 'linear' detection system and an 'area' system. In terms of cost effectiveness and ease of construction, the linear system (Figures 15 and 16) was observed to be most suitable and it was successfully adopted at the landfill site.

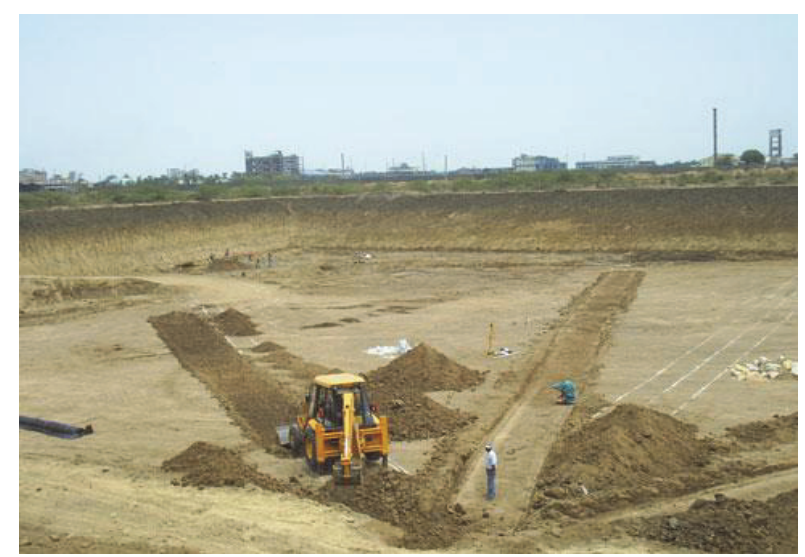

Fig. 15. LDS alignment at Ankleshwar HW landfill

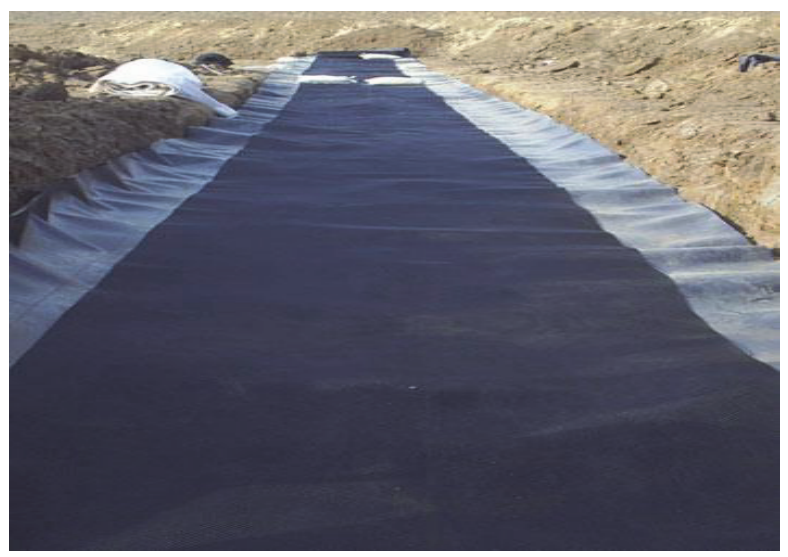

Fig. 16. LDS components, Ankleshwar HW landfill

\section{REFERENCES}

1) Benson, C.H., Khire, M. (1995): Earthen covers for semi-arid and arid climates, ASCE, Geotechnical Special Publication No. 53, Proc. Landfill Closures-Environmental Protection and Land Recovery, R. Jeffrey Dunn and Udai P. Singh, Eds., New York.

2) Central Pollution control Board (CPCB), MoEF (Ministry of Environment and Forests) (2001): Criteria for Hazardous Waste Landfills, Series: HAZWAMS/17 /2000-01, New Delhi, India.

3) Datta, Manoj. (2012): Geotechnology for environmental control at waste disposal sites, Indian Geotechnical Journal, 42(1), 1-36.

4) Hauser, V.L. et. al. (2005): Models for hydrologic design of evapotranspiration landfill covers, Environ. Sci. Technol., 39(18), 7226-7233.

5) Jose, M. K., and Majumdar, P. K. (2003): Application of help model for hydrologic evaluation of a landfill, In Wastewater
Treatment and Waste Management: Proceedings of the International Conference on Water and Environment (WE2003), December 15-18, Bhopal, India,2, 373.

6) Khire, M.V., Craig H. Benson. and Peter J. Bosscher. (1997): Water balance modelling of earthen final covers, Geotech. Geoenviron. Eng., 123(8), 744-754.

7) Koerner, R. and Daniel, D.E. (1994): A suggested methodology for assessing the technical equivalency of GCLs to CCLs. geosynthetic clay liners, Proceedings in an International Symposium, Koerner, R.M., Gartung, E., and H. Zanzinger (Eds.), A.A. Balkema, Rotterdam, Netherlands, 73-98.

8) Mazzieri, F. and Pasqualini, E. (2000): Permeability of damaged geosynthetic clay liners, Geosynthetics International, 7 (2), 101-118.

9) Parameswaran, P.N. (2013): Hazardous waste management TSDF operations and concerns, National seminar on water and ground pollution: prediction, prevention and control; May 04, 2013, VICT, Ahmedabad, India.

10) Peyton, R. Lee. and Paul R. Schroeder. (1988): Field verification of HELP model for landfills. Environ. Eng., 114(2), 247-269.

11) Phillips, P. and Eberle, M. (2001): The use of geosynthetic clay Liners (GCL's) in containment applications- An Australian perspective, Environmental Geotechnics, 365-371.

12) Rowe, R.K., Quigley, R.M., Brachman, R.W.I. and Booker, J.R. (2004): Barrier systems for waste disposal facilities. 2nd London.

Ed. Taylor \& Francis Books Ltd. (E \& FN Spon),

13) Schroeder, P. R., et. al. (1994a): The hydrologic evaluation of landfill performance (HELP) model Engineering documentation for version 3, EPA/600/R-94/168a, U.S. Environmental Protection Agency, Cincinnati, Ohio, USA.

14) Schroeder, P. R. et. al. (1994b): The hydrologic evaluation of landfill performance (HELP) model Engineering documentation for version 3, EPA/600/R-94/168b, U.S. EPA, Cincinnati, Ohio, USA.

15) U.S. Environmental Protection Agency USEPA (1993): Subpart F-Closure and Post-Closure, In: Solid Waste Disposal Facility Criteria, Technical Manual, EPA530-R-93017, 322-332.

16) William H. A., Benson, C.H. and Preecha Apiwantragoon. (2013): Field hydrology of landfill final covers with composite barrier layers, Geotech. Geoenviron. Eng., 139(1), $1-12$.

17) William H. A., et al. (2004): Field water balance of landfill final covers, Environ Qual., 33(6), 2317-2332.

18) Williams, K.H. (1989): Random nature of soil porosity and related properties, Eng. Mechanics, 115(5), 1129-1133. 